\title{
Improvement in Saccharification Yield of Mixed Rumen Enzymes by Identification of Recalcitrant Cell Wall Constituents Using Enzyme Fingerprinting
}

\author{
Ajay Badhan, ${ }^{1}$ Yu-Xi Wang, ${ }^{1}$ Robert Gruninger, ${ }^{1}$ Donald Patton, ${ }^{2}$ \\ Justin Powlowski, ${ }^{2}$ Adrian Tsang, ${ }^{2}$ and Tim A. McAllister ${ }^{1}$ \\ ${ }^{1}$ Agriculture and Agri-Food Canada, Lethbridge Research Centre, Lethbridge, AB, Canada T1H 4P4 \\ ${ }^{2}$ Centre for Structural and Functional Genomics, Concordia University, Montreal, QC, Canada H4B 1R6 \\ Correspondence should be addressed to Tim A. McAllister; tim.mcallister@agr.gc.ca
}

Received 19 November 2014; Revised 15 January 2015; Accepted 16 January 2015

Academic Editor: Thean-Hock Tang

Copyright (c) 2015 Ajay Badhan et al. This is an open access article distributed under the Creative Commons Attribution License, which permits unrestricted use, distribution, and reproduction in any medium, provided the original work is properly cited.

Identification of recalcitrant factors that limit digestion of forages and the development of enzymatic approaches that improve hydrolysis could play a key role in improving the efficiency of meat and milk production in ruminants. Enzyme fingerprinting of barley silage fed to heifers and total tract indigestible fibre residue (TIFR) collected from feces was used to identify cell wall components resistant to total tract digestion. Enzyme fingerprinting results identified acetyl xylan esterases as key to the enhanced ruminal digestion. FTIR analysis also suggested cross-link cell wall polymers as principal components of indigested fiber residues in feces. Based on structural information from enzymatic fingerprinting and FTIR, enzyme pretreatment to enhance glucose yield from barley straw and alfalfa hay upon exposure to mixed rumen-enzymes was developed. Prehydrolysis effects of recombinant fungal fibrolytic hydrolases were analyzed using microassay in combination with statistical experimental design. Recombinant hemicellulases and auxiliary enzymes initiated degradation of plant structural polysaccharides upon application and improved the in vitro saccharification of alfalfa and barley straw by mixed rumen enzymes. The validation results showed that microassay in combination with statistical experimental design can be successfully used to predict effective enzyme pretreatments that can enhance plant cell wall digestion by mixed rumen enzymes.

\section{Introduction}

Rising grain prices heightened concerns over the use of food as feed for livestock production and the negative impacts of annual crops on carbon sequestration and biodiversity has prompted research into finding ways to increase the use of fibrous forage in ruminant diets. Plant cell walls can constitute a primary source of nutritional energy for ruminants. However for many types of forage, less than $50 \%$ of the cell wall fraction is digested and utilized by the ruminant host [1]. Substantial benefits would be realized if a greater percentage of this potential energy was made available for fermentation in the rumen through an increase in the digestibility of the cell wall fraction.
Fiber digestion in ruminants occurs primarily in the rumen and cecum. Generally, the amount of fiber digested in the lower tract is relatively small, with the rumen being the primary site of digestion. The ruminal microbial population secrets diverse hydrolases to degrade and ferment structural carbohydrates in plant cell walls. The physical and chemical nature of forages can present a barrier to their complete digestion in the rumen [2]. Therefore, prior knowledge about the structural aspects of cell wall polymers that limit digestion is critical to identifying efficient enzymatic pretreatments. In this study enzyme fingerprinting was used in combination with Flourier infrared spectroscopy (FTIR) to identify recalcitrant factors that limit fiber digestion by mixed rumen enzymes. 
Exogenous enzymes have been used to remove antinutritional factors from feeds, to increase the digestibility of existing nutrients, and to supplement the activity of the endogenous enzymes. To date, they have primarily been used in poultry and swine production $[3,4]$. In cattle, the addition of cellulases and xylanases directly to feeds has been shown to increase the in vivo numbers of fibrolytic rumen bacteria that utilize the secondary products of cellulose digestion [5]. Feedstuffs are structurally complex; each substrate presents its own set of recalcitrant components that limit the extent of feed digestion in the rumen. Ultimately, enzyme pretreatments should be designed specifically to overcome the constraints limiting digestion of different types of forages. There have been number of reports recently focusing on development of synthetic formulation of lignocellulolytic enzymes and chemical pretreatments for biomass use in biofuel production. Synthetic enzyme mixtures for ammonia fiber expansion (AFEX) treated corn stover deconstruction have been reported [6,7]. Similarly optimized synthetic mixture of enzymes from Trichoderma reesei for hydrolysis of steam exploded wheat straw [8] and enzyme formulations to enhance performance of commercial enzymes against alkaline pretreated barley straw and alfalfa have been recently reported [9].

In this study we sought to use a microassay procedure in combination with statistical experimental design to predict the optimized synergy between enzyme prehydrolysis and maximum solubilization of cellulose by mixed rumen enzymes (rumen endogenous enzymes). The optimized enzyme pretreatment conditions were then validated using a scale-up assay. A similar approach using a combination of statistical design and microplate technique for enzymatic hydrolysis with comparable protein to biomass load and reaction volumes has been reported previously $[9,10]$. The present work describes the use of a technique to specifically assay very small quantities of enzymes, enabling the screening of a large number of recombinant enzymes from novel sources for their ability to enhance the digestion of plant cell walls by mixed rumen enzymes. It is expected that the method described here will facilitate the development of enzyme cocktails for use as ruminant feed additives.

\section{Material and Method}

2.1. Source of Enzymes, Production, and Biochemical Characterization of Recombinant Enzymes. The source of recombinant enzymes, their expression, biochemical characterisation (Table 1), along with details about commercial enzymes, and the methods used to prepare mixed rumen enzymes have been previously reported [9].

2.2. Statistical Design. Simplex-lattice designs were created using Design-Expert software (Version 8.0; Stat-Ease, Inc., Minneapolis, MN; http://www.statease.com) as described earlier [9] with slight modifications. Details of augmented special quadratic design for experiment number 1 (six components) and experiment number 2 (seven components) with 28 and 41 separate assays are shown in Tables 2, 3, 4, and 5 , respectively. The relative abundance of core enzymes (i.e., Accellerase 1500 and Accellerase XC) was set to vary from $25 \%$ to $75 \%$, while upper and lower limits for fungal enzymes were set between $50 \%$ and $100 \%$ in assay mixtures for experiment 1 , whereas, in order to optimize the efficiency of enzymatic prehydrolysis, upper and lower limits for all enzymes were set to vary from $100 \%$ to $0 \%$ in experiment 2 .

\subsection{Experimental Detail}

2.3.1. Experiment Number 1: Enzyme Fingerprinting of Alkaline Peroxide Pretreated (AP) Barley Silage and Total Tract Indigested Fiber Residues (TIFR). Enzymatic fingerprinting of AP treated barley silage and total tract indigestible fiber residue (TIFR) was used in this study to gain insight into the recalcitrant components in plant cell walls that may respond to enzyme pretreatment and enhance the activity of mixed rumen enzymes. Alkaline peroxide treatment was used for selective delignification of cell walls in order to enable enzymes to access inner core cellulose and hemicellulose which would otherwise have remained inaccessible.

(a) Alkaline Peroxide Pretreatment of Barley Silage and TIFR. Heifers (five) were fed a barley silage-based diet $(70: 30$ barley silage to barley grain) with approximately $65 \%$ of dietary neutral detergent fiber coming from barley silage, as described earlier [11]. Samples $(n=5)$ of barley silage were collected over the course of the feeding experiment, freeze dried and ground though a $1.0 \mathrm{~mm}$ screen. Representative faecal samples were collected for three days (once a day) from each heifer as reported previously and washed (6-7 times) in $50 \mathrm{mM}$ citrate buffer to remove solubles and to recover the final fiber residue. The material obtained after washing was termed total tract indigested fiber residue (TIFR), with the three samples being pooled. Barley silage was also washed through cheese cloth to obtain a similar particle size. Washed TIFR and barley silage were freeze dried and pretreated with alkaline peroxide using the procedure described earlier [9].

(b) Enzymatic Fingerprinting of Alkaline Peroxide Treated Barley Silage and TIFR. Enzymatic digestion of AP treated barley silage and TIFR was carried out in microassays as reported earlier [9]. Respective enzyme volumes containing defined protein contents for each reaction mixture were calculated according to statistical design detailed in Tables 2 and 3 and dispensed into a substrate slurry as described previously [9]. Samples were incubated at $50^{\circ} \mathrm{C}$ for $48 \mathrm{~h}$ on a rotating shaker at $10 \mathrm{rpm}$. After incubation, tubes were centrifuged at $1,500 \times \mathrm{g}$ for $5 \mathrm{~min}$ and the supernatants $(100 \mu \mathrm{L})$ were heated at $90^{\circ} \mathrm{C}$ for $10 \mathrm{~min}$ to inactivate enzymes prior to determination of liberated glucose and xylose.

2.3.2. Experiment Number 2: Effect of Enzymatic Prehydrolysis on Sugar Release from Alfalfa Hay and Barley Straw Exposed to Mixed Rumen Enzymes In Vitro. Enzyme prehydrolysis to enhance glucose yield from plant cell walls by mixed rumen enzymes was developed based on relative abundance data from the enzyme fingerprinting conducted in experiment 1 and differential Fourier transform infrared spectroscopy (FTIR) analysis of barley silage versus TIFR. The main 


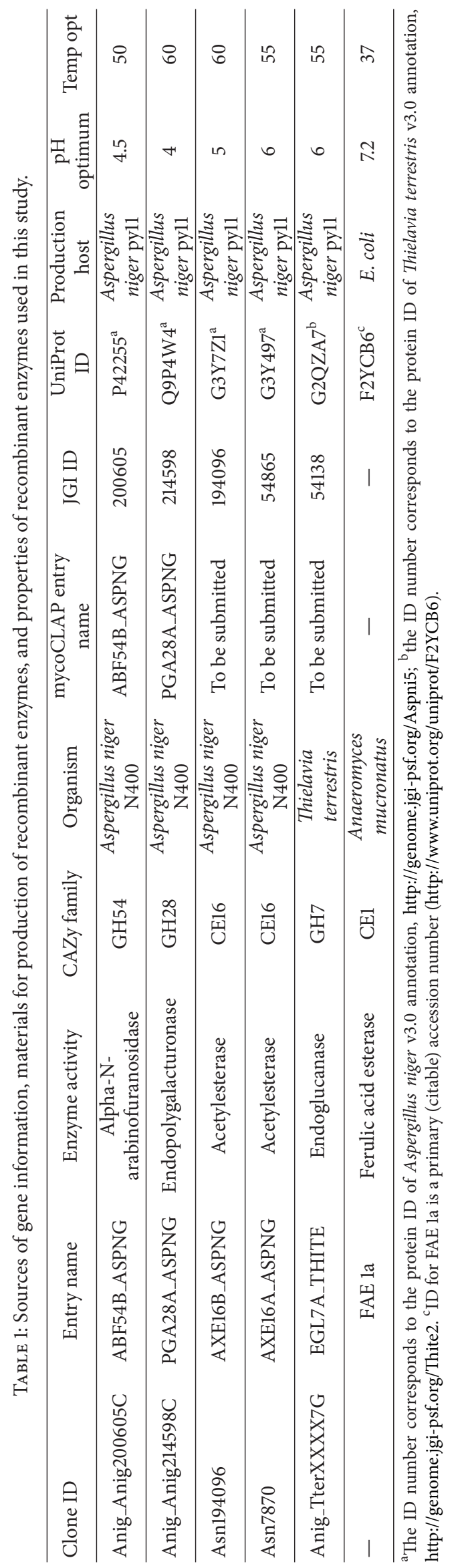


TABLE 2: Experimental design for comprehensive digestion of barley silage.

\begin{tabular}{|c|c|c|c|c|c|c|c|c|c|}
\hline \multicolumn{2}{|c|}{ Std Run } & $\begin{array}{l}\text { Component } 1 \\
\text { A: acell } 1500\end{array}$ & $\begin{array}{c}\text { Component } 2 \\
\text { B: acell XC }\end{array}$ & $\begin{array}{l}\text { Component } 3 \\
\text { C: E-BGLUC }\end{array}$ & $\begin{array}{c}\text { Component } 4 \\
\text { D: FAE }\end{array}$ & $\begin{array}{c}\text { Component } 5 \\
\text { E: AXE16A_ASPNG }\end{array}$ & $\begin{array}{c}\text { Component } 6 \\
\text { F: EGL7A_THITE }\end{array}$ & $\begin{array}{l}\text { Response } 1 \\
\text { Glucose rel } \\
\end{array}$ & $\begin{array}{c}\text { Response } 2 \\
\text { Xylose rel } \\
\end{array}$ \\
\hline 12 & 1 & 0.250 & 0.500 & 0.250 & 0.000 & 0.000 & 0.000 & 153.436 & 36.7534 \\
\hline 4 & 2 & 0.250 & 0.250 & 0.000 & 0.500 & 0.000 & 0.000 & 166.702 & 30.6087 \\
\hline 10 & 3 & 0.500 & 0.250 & 0.000 & 0.000 & 0.250 & 0.000 & 172.536 & 50.8231 \\
\hline 24 & 4 & 0.292 & 0.292 & 0.292 & 0.042 & 0.042 & 0.042 & 182.126 & 48.4112 \\
\hline 3 & 5 & 0.250 & 0.250 & 0.500 & 0.000 & 0.000 & 0.000 & 135.056 & 32.2167 \\
\hline 20 & 6 & 0.250 & 0.250 & 0.000 & 0.250 & 0.000 & 0.250 & 190.597 & 52 \\
\hline 1 & 7 & 0.750 & 0.250 & 0.000 & 0.000 & 0.000 & 0.000 & 152.397 & 39.9119 \\
\hline 28 & 8 & 0.333 & 0.333 & 0.083 & 0.083 & 0.083 & 0.083 & 177 & 54 \\
\hline 18 & 9 & 0.250 & 0.250 & 0.250 & 0.000 & 0.000 & 0.250 & 203.223 & 69.6018 \\
\hline 15 & 10 & 0.250 & 0.500 & 0.000 & 0.000 & 0.000 & 0.250 & 178.849 & 65.2948 \\
\hline 8 & 11 & 0.500 & 0.250 & 0.250 & 0.000 & 0.000 & 0.000 & 135.456 & 37.5574 \\
\hline 11 & 12 & 0.500 & 0.250 & 0.000 & 0.000 & 0.000 & 0.250 & 251.492 & 78.2159 \\
\hline 25 & 13 & 0.292 & 0.292 & 0.042 & 0.292 & 0.042 & 0.042 & 172.776 & 44.9655 \\
\hline 14 & 14 & 0.250 & 0.500 & 0.000 & 0.000 & 0.250 & 0.000 & 175.093 & 57.3124 \\
\hline 13 & 15 & 0.250 & 0.500 & 0.000 & 0.250 & 0.000 & 0.000 & 179.968 & 49.4449 \\
\hline 17 & 16 & 0.250 & 0.250 & 0.250 & 0.000 & 0.250 & 0.000 & 156.313 & 58.2887 \\
\hline 9 & 17 & 0.500 & 0.250 & 0.000 & 0.250 & 0.000 & 0.000 & 169.659 & 44.1616 \\
\hline 22 & 18 & 0.542 & 0.292 & 0.042 & 0.042 & 0.042 & 0.042 & 209.776 & 52.2014 \\
\hline 26 & 19 & 0.292 & 0.292 & 0.042 & 0.042 & 0.292 & 0.042 & 190 & 63.6294 \\
\hline 23 & 20 & 0.292 & 0.542 & 0.042 & 0.042 & 0.042 & 0.042 & 190 & 52 \\
\hline 7 & 21 & 0.500 & 0.500 & 0.000 & 0.000 & 0.000 & 0.000 & 215.61 & 50 \\
\hline 21 & 22 & 0.250 & 0.250 & 0.000 & 0.000 & 0.250 & 0.250 & 182.605 & 53.6945 \\
\hline 27 & 23 & 0.292 & 0.292 & 0.042 & 0.042 & 0.042 & 0.292 & 200 & 62 \\
\hline 6 & 24 & 0.250 & 0.250 & 0.000 & 0.000 & 0.000 & 0.500 & 198.828 & 65.6968 \\
\hline 5 & 25 & 0.250 & 0.250 & 0.000 & 0.000 & 0.500 & 0.000 & 215.21 & 77.9288 \\
\hline 16 & 26 & 0.250 & 0.250 & 0.250 & 0.250 & 0.000 & 0.000 & 182.845 & 37.5 \\
\hline 2 & 27 & 0.250 & 0.750 & 0.000 & 0.000 & 0.000 & 0.000 & 180.208 & 61.16 \\
\hline 19 & 28 & 0.250 & 0.250 & 0.000 & 0.250 & 0.250 & 0.000 & 163.506 & 49.6172 \\
\hline
\end{tabular}

objective of this experiment was to formulate mixed rumen enzymes in combination with recombinant enzymes in ratios that enhance plant cell wall digestion . Recombinant glycosyl hydrolases (GH) (endoglucanase GH7 (EGL7A_THITE)) and auxiliary enzymes, that is, esterase (AXE16A_ASPNG, AXE16B_ASPNG, FAE 1a), were used with barley straw, whereas hemicellulase polygalacturonase (PGA28A_ASPNG) and $\alpha$-arabinofuranosidase (ABF54B_ASPNG) were used with alfalfa hay.

Alfalfa hay and barley straw were first ground to pass through a $1 \mathrm{~mm}$ screen and then were suspended separately at a final concentration of $0.5 \%$ in $50 \mathrm{mM}$ sodium citrate ( $\mathrm{pH} 5.0$, containing $5 \mu \mathrm{g} / \mathrm{mL}$ tetracycline, $5 \mu \mathrm{g} / \mathrm{mL}$ cycloheximide, and $0.02 \%$ sodium azide). While the slurry was kept in suspension using a paddle reservoir designed for dispensing pharmaceutical beads (Biomek FXP, Model VP 756C-1P100, V\&P Scientific, Inc., San Diego, CA), a total of $200 \mu \mathrm{L}$ (duplicate) of substrate slurry was dispensed into a mini-Eppendorf tube as described previously [9]. Defined protein content of each constituent enzyme for every reaction mixture (prehydrolysis) was calculated and dispensed according to the experimental design (Tables 3 and 4).
Control samples were incubated without enzymes for $48 \mathrm{~h}$ at $50^{\circ} \mathrm{C}$ (total protein load $15 \mathrm{mg}$ protein per g of glucan). After incubation, enzymes were inactivated by heating at $90^{\circ} \mathrm{C}$ for $15 \mathrm{~min}$. Samples were allowed to cool and were subsequently centrifuged $(1,500 \times \mathrm{g}$ for $3 \mathrm{~min})$ three times with $50 \mathrm{mM}$ sodium citrate $(\mathrm{pH} 5.0$, containing $5 \mu \mathrm{g} / \mathrm{mL}$ tetracycline, $5 \mu \mathrm{g} / \mathrm{mL}$ cycloheximide, and $0.02 \%$ sodium azide). Residues were added to mixed rumen enzymes at final concentration of $15 \mathrm{mg}$ protein per $\mathrm{g}$ of glucan and incubated for further $48 \mathrm{~h}$ at $50^{\circ} \mathrm{C}$. After incubation, the tubes were centrifuged at $1,500 \times \mathrm{g}$ for $3 \mathrm{~min}$ to separate the solid residue from the supernatants $(100 \mu \mathrm{L})$ which were transferred into Costar 96-well plates and heated at $100^{\circ} \mathrm{C}$ for $10 \mathrm{~min}$ to inactivate enzymes.

2.4. Glucose and Xylose Assay, Scale-Up Assay, Total Glucan Content, and Attenuated Total Reflectance Fourier Transform Infrared Spectroscopy (ATR FT-IR) of Barley Silage and TIFR. Released glucose and xylose and total glucan contents of barley silage and TIFR were determined in a scale-up assay as previously reported [9]. ATR FT_IR analysis was also performed as documented earlier [12]. 
TABLE 3: Experimental design for comprehensive digestion of TIFR.

\begin{tabular}{|c|c|c|c|c|c|c|c|c|c|}
\hline \multicolumn{2}{|c|}{ Std Run } & $\begin{array}{l}\text { Component } 1 \\
\text { A: acell } 1500\end{array}$ & $\begin{array}{c}\text { Component } 2 \\
\text { B: acell XC }\end{array}$ & $\begin{array}{l}\text { Component } 3 \\
\text { C: E-BGLUC }\end{array}$ & $\begin{array}{c}\text { Component } 4 \\
\text { D: FAE }\end{array}$ & $\begin{array}{c}\text { Component } 5 \\
\text { E: AXE16A_ASPNG }\end{array}$ & $\begin{array}{c}\text { Component } 6 \\
\text { F: EGL7A_THITE }\end{array}$ & $\begin{array}{l}\text { Response } 1 \\
\text { Glucose rel } \\
\end{array}$ & $\begin{array}{c}\text { Response } 2 \\
\text { Xylose rel }\end{array}$ \\
\hline 12 & 1 & 0.250 & 0.500 & 0.250 & 0.000 & 0.000 & 0.000 & 65.7698 & 36.3515 \\
\hline 4 & 2 & 0.250 & 0.250 & 0.000 & 0.500 & 0.000 & 0.000 & 64.731 & 27.1631 \\
\hline 10 & 3 & 0.500 & 0.250 & 0.000 & 0.000 & 0.250 & 0.000 & 90.6233 & 59.6095 \\
\hline 24 & 4 & 0.292 & 0.292 & 0.292 & 0.042 & 0.042 & 0.042 & 91.8221 & 44.6784 \\
\hline 3 & 5 & 0.250 & 0.250 & 0.500 & 0.000 & 0.000 & 0.000 & 78.6361 & 31.585 \\
\hline 20 & 6 & 0.250 & 0.250 & 0.000 & 0.250 & 0.000 & 0.250 & 87.5866 & 49.5597 \\
\hline 1 & 7 & 0.750 & 0.250 & 0.000 & 0.000 & 0.000 & 0.000 & 84.0703 & 42.3813 \\
\hline 28 & 8 & 0.333 & 0.333 & 0.083 & 0.083 & 0.083 & 0.083 & 87 & 47.0904 \\
\hline 18 & 9 & 0.250 & 0.250 & 0.250 & 0.000 & 0.000 & 0.250 & 89.8242 & 54.4985 \\
\hline 15 & 10 & 0.250 & 0.500 & 0.000 & 0.000 & 0.000 & 0.250 & 94.2994 & 53.6371 \\
\hline 8 & 11 & 0.500 & 0.250 & 0.250 & 0.000 & 0.000 & 0.000 & 85.9084 & 37.0406 \\
\hline 11 & 12 & 0.500 & 0.250 & 0.000 & 0.000 & 0.000 & 0.250 & 100.053 & 56.2213 \\
\hline 25 & 13 & 0.292 & 0.292 & 0.042 & 0.292 & 0.042 & 0.042 & 90.4635 & 40 \\
\hline 14 & 14 & 0.250 & 0.500 & 0.000 & 0.000 & 0.250 & 0.000 & 77.0378 & 56.6807 \\
\hline 13 & 15 & 0.250 & 0.500 & 0.000 & 0.250 & 0.000 & 0.000 & 95.7379 & 41.9219 \\
\hline 17 & 16 & 0.250 & 0.250 & 0.250 & 0.000 & 0.250 & 0.000 & 117.315 & 63.1126 \\
\hline 9 & 17 & 0.500 & 0.250 & 0.000 & 0.250 & 0.000 & 0.000 & 90.5434 & 35.2029 \\
\hline 22 & 18 & 0.542 & 0.292 & 0.042 & 0.042 & 0.042 & 0.042 & 93 & 52.7182 \\
\hline 26 & 19 & 0.292 & 0.292 & 0.042 & 0.042 & 0.292 & 0.042 & 84.39 & 58.5758 \\
\hline 23 & 20 & 0.292 & 0.542 & 0.042 & 0.042 & 0.042 & 0.042 & 90.7032 & 53.2351 \\
\hline 7 & 21 & 0.500 & 0.500 & 0.000 & 0.000 & 0.000 & 0.000 & 86.9473 & 44.3338 \\
\hline 21 & 22 & 0.250 & 0.250 & 0.000 & 0.000 & 0.250 & 0.250 & 82.7917 & 50.536 \\
\hline 27 & 23 & 0.292 & 0.292 & 0.042 & 0.042 & 0.042 & 0.292 & 85.7485 & 53 \\
\hline 6 & 24 & 0.250 & 0.250 & 0.000 & 0.000 & 0.000 & 0.500 & 98.8546 & 59.6095 \\
\hline 5 & 25 & 0.250 & 0.250 & 0.000 & 0.000 & 0.500 & 0.000 & 60.2557 & 60 \\
\hline 16 & 26 & 0.250 & 0.250 & 0.250 & 0.250 & 0.000 & 0.000 & 64.3314 & 31.8147 \\
\hline 2 & 27 & 0.250 & 0.750 & 0.000 & 0.000 & 0.000 & 0.000 & 93.2605 & 46.6884 \\
\hline 19 & 28 & 0.250 & 0.250 & 0.000 & 0.250 & 0.250 & 0.000 & 84.7096 & 48.2389 \\
\hline
\end{tabular}

2.5. Data Analysis. Glucose and xylose released in each assay served as the response for experimental design in experiment 1 , while in experiment 2 assay responses were expressed as a percentage yield of glucose in prehydrolyzed samples relative to the controls, where the residues were not prehydrolyzed. For experiments 1 and 2, ANOVA calculations were conducted and are reported in Tables 6 and 7, respectively.

\section{Results and Discussions}

One increasingly important aspect of modern livestock production is the use of feed additives that aim to improve the efficiency of feed utilization and thereby contribute to the sustainability of meat and milk production. In monogastrics, exogenous enzymes have been used to remove antinutritional factors from feeds, to increase the digestibility of existing nutrients, and to complement the activity of endogenous enzymes [3, 4]. Digestion of plant cell walls to volatile fatty acids by ruminal microorganisms is a key step in the derivation of energy from recalcitrant substrates such as cereal straws by ruminants. Sufficient intake of digestible forage with an appropriate profile of nutrients is critical for optimal ruminant production. Hence, identification of those plant cell wall components that resist rumen digestion is vital for developing effective and efficient additives that improve the utilization of forages by ruminants. In this study, we used enzymatic fingerprinting of undigested fiber residue that has passed through the digestive tract (TIFR) to identify major undigested components of feed. We used two commercial enzymes (Accellerase 1500 and Accellerase XC) as core enzyme preparations as these two preparations are comprehensive and are routinely used for cell wall digestion. An enzyme cocktail containing 49\% Accellerase 1500, 25\% Accellerase XC, 25\% of endoglucanase EGL7A_THITE, and $1 \%$ of $\beta$-glucosidase E-BGLUC activity resulted in the highest yield of glucose and xylose from AP treated barley silage (Figure 1(a)). Interestingly, enzyme fingerprinting of AP treated TIFR from cattle fed barley silage showed the highest sugar yield for the enzyme mix containing supplemental acetyl xylan esterase AXE16B_ASPNG (25\%) and $\beta$-glucosidase E-BGLUC (25\%) activity in addition to Accellerase 1500 (25\%) and Accellerase XC (25\%) (Figure 1(b)). These results suggest that effective digestion of AP treated TIFR increases with supplemental acetyl xylan 


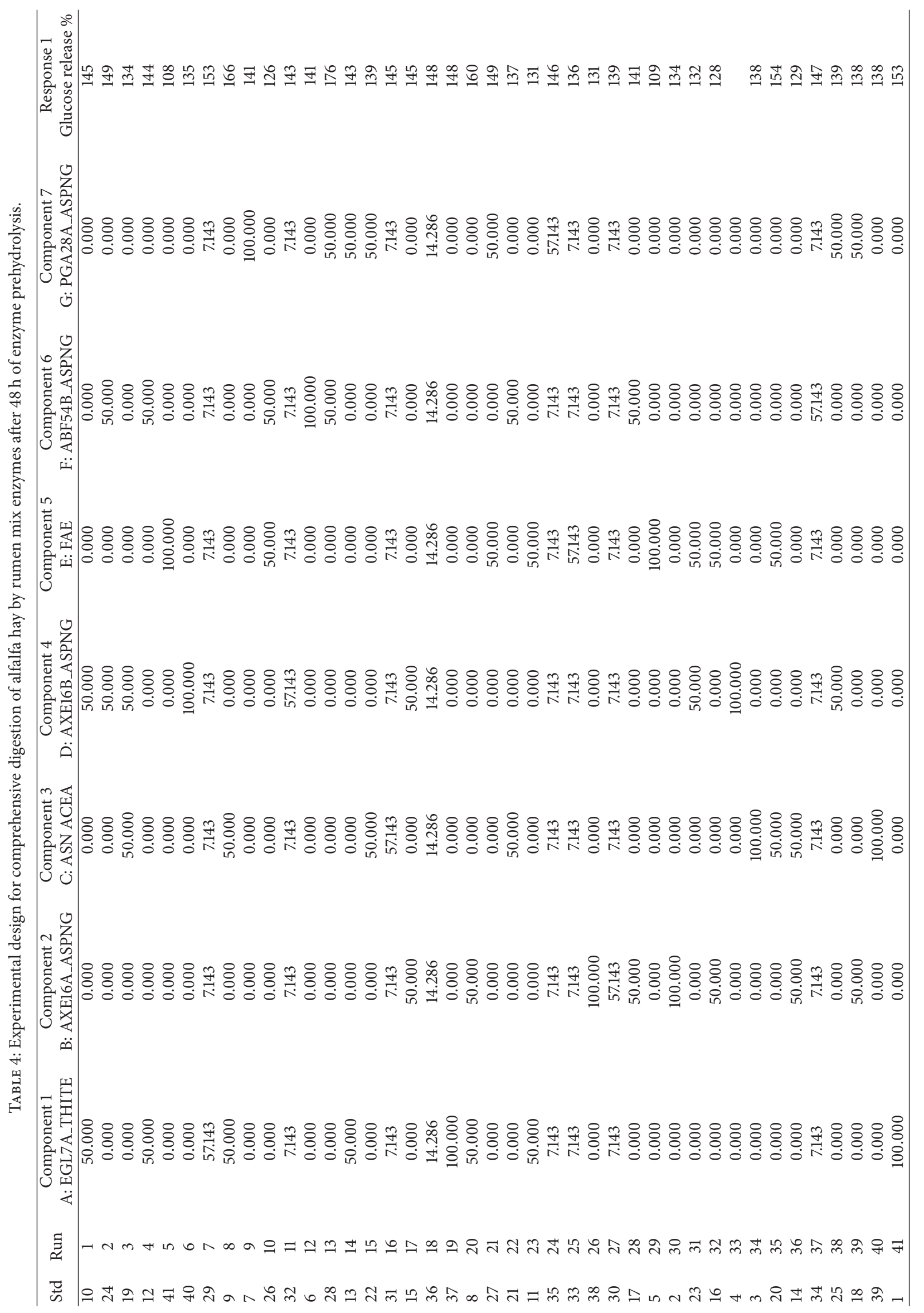




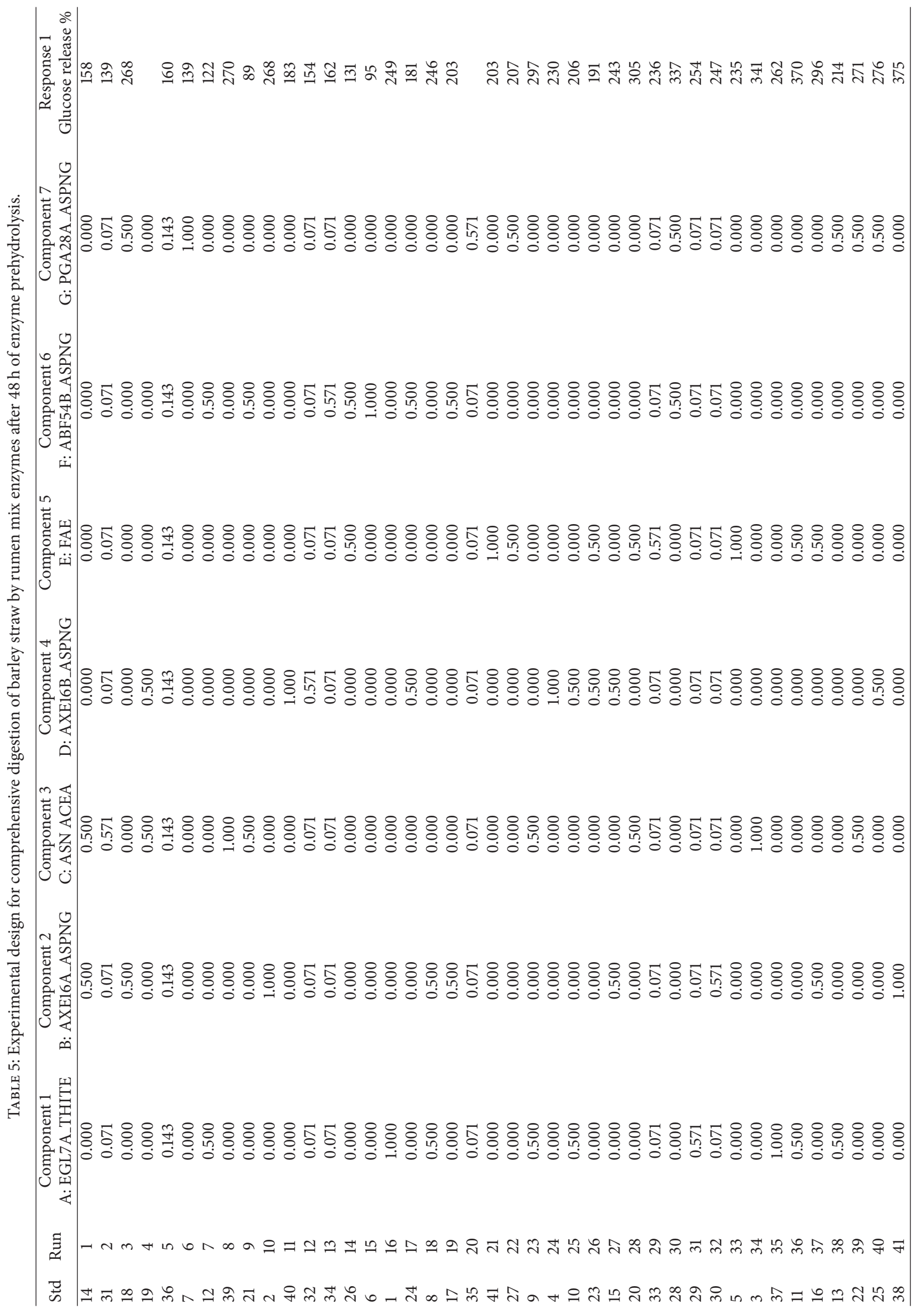


TABLe 6: ANOVA calculations of $F$-value, $P$ value, $R^{2}$, adjusted $R^{2}$, predicted $R^{2}$, and adequate precision as calculated by the Design-Expert software for enzymatic fingerprinting of barley silage and tract indigested fiber residue (TIFR).

\begin{tabular}{|c|c|c|c|c|c|c|c|c|}
\hline Source & Enzyme source & $F$-value & $P$ value & $R$-square & $\begin{array}{l}\text { Adjusted } \\
R \text {-square }\end{array}$ & $\begin{array}{l}\text { Predicted } \\
R \text {-square }\end{array}$ & $\begin{array}{c}\text { Difference between } \\
\text { Adj and Pred } \\
R \text {-square }\end{array}$ & $\begin{array}{l}\text { Adequate } \\
\text { precision }\end{array}$ \\
\hline $\begin{array}{l}\text { AP pretreated } \\
\text { barley silage feed }\end{array}$ & $\begin{array}{c}\text { Accell1500 + AccellXC + } \\
\text { EGL7A_THITE + } \\
\text { E-BGLUC }\end{array}$ & 129.1 & $<0.0001$ & 0.98 & 0.97 & 0.86 & 0.11 & 52.3 \\
\hline $\begin{array}{l}\text { AP pretreated } \\
\text { TIFR }\end{array}$ & $\begin{array}{c}\text { Accell1500 + AccellXC + } \\
\text { AXE16B_ASPNG + } \\
\text { E-BGLUC }\end{array}$ & 16.60 & $<0.0001$ & 0.88 & 0.83 & 0.71 & 0.12 & 16.8 \\
\hline
\end{tabular}

TABle 7: ANOVA calculations of $F$-value, $P$ value, $R^{2}$, adjusted $R^{2}$, predicted $R^{2}$, and adequate precision as calculated by the Design-Expert software for enzymatic prehydrolysis of alfalfa hay and barley straw on final saccharification yield from rumen mix enzyme digestion.

\begin{tabular}{lccccccc}
\hline Feedstock & Enzyme source & $F$-value & $P$ value & $R$-square & $\begin{array}{c}\text { Adjusted } \\
R \text {-square }\end{array}$ & $\begin{array}{c}\text { Predicted } \\
R \text {-square }\end{array}$ & $\begin{array}{c}\text { Difference between } \\
\text { Adj and Pred } \\
R \text {-square }\end{array}$ \\
\hline Alfalfa & $\begin{array}{c}\text { Enzyme pretreatments } \\
\text { followed by rumen } \\
\text { enzyme mix }\end{array}$ & 129.1 & $<0.0001$ & 0.98 & 0.97 & 0.86 & 0.11 \\
\hline Barley & $\begin{array}{c}\text { Enzyme pretreatments } \\
\text { followed by rumen } \\
\text { enzyme mix }\end{array}$ & 16.60 & $<0.0001$ & 0.88 & 0.83 & 0.71 & 0.12 \\
\hline
\end{tabular}

esterase as well as $\beta$-glucosidase activity. With $22-50 \%$ of xylose residues being acetylated at the $0-2$ and or $0-3$ positions, acetylation has been reported to be an important factor influencing the digestibility of plant cell walls in ruminants [13]. In addition, arabinoxylan one of the main components in hemicellulose that forms the backbone structure of $\beta-1,4$ linked xylose with arabinose side chains has been reported to be ester-linked to p-coumaric and ferulic acid and crosslinked to lignin via ferulic acid $[14,15]$.

Relatively lower yields were observed when the enzyme mix contained a higher percentage of core enzymes (only Accellerase 1500 and Accellerase XC, Tables 2 and 3). However, assays with high xylanase levels (Accellerase XC) produced higher glucose and xylose yield as compared to assays with high endoglucanase (Accellerase 1500) both from barley silage and TIFR (Tables 2 and 3 ). These results reflect the layered structure of cellulose and xylan chains within plant cell walls as xylan hydrolysis significantly improved the activity of cellulases against cellulose. Comparative analysis of results from enzymatic fingerprinting experiment for AP treated barley silage versus AP treated TIFR demonstrates that TIFR still contains a significant amount of residual sugars that could be released if digested with a suitable enzyme cocktail (Figure 1). Comprehensive saccharification of AP pretreated barley silage released $252 \mathrm{mg} / \mathrm{g}$ of glucose and $78 \mathrm{mg} / \mathrm{g}$ of xylose while $117 \mathrm{mg} / \mathrm{g}$ of glucose and $63 \mathrm{mg} / \mathrm{g}$ of xylose were released from AP TIFR. Thus, significant glucose (40\%) and xylose (80\%) were still recoverable from TIFR even after it had been subject to digestion within the intestinal tract of cattle (Figure 1). These results also suggest that cattle feces have considerable potential as a feedstock for biofuel production. Using manure as a feedstock for bioethanol production addresses some of the serious concerns raised against first generation biofuels in terms of their impact on biodiversity, competition for fuel versus food and carbon emissions.

The high abundance of xylose in AP treated TIFR and critical requirement of acetyl xylan esterase reflects (Figure 1(b)) the recalcitrant nature of xylan and its crosslinked nature within the cell wall architecture. An abundance of undigested xylan and esterified hemicellulose components were also supported by differential spectra of barley silage versus TIFR by FTIR analysis. Peaks within the range of $1020 \mathrm{~cm}^{-1}$ to $1130 \mathrm{~cm}^{-1}$ corresponded to undigested arabinoglucuronoxylan, xyloglucan, arabinan, and pectin [16] and were reflective of an abundance of cross-linked hemicellulose within TIFR (Figure 2). Lignin was also concentrated in TIFR as indicated by spectral differences at $1508 \mathrm{~cm}^{-1}$ (aromatic skeletal vibration in lignin), $1541 \mathrm{~cm}^{-1}(\mathrm{C}-\mathrm{H}$ deformations; asymmetrical in $-\mathrm{CH}_{3}$ and $\left.-\mathrm{CH}_{2}\right), 1653 \mathrm{~cm}^{-1}$ (adsorbed $\mathrm{O}-\mathrm{H}$ and conjugated $\mathrm{C}-\mathrm{O})$, and $1688 \mathrm{~cm}^{-1}(\mathrm{C}=\mathrm{O}$ in lignin) (Figure 2) [17]. Cross-linked esterified xylan and pectin in undigested residue were evident at peak $1714 \mathrm{~cm}^{-1}$ ( $\mathrm{C}=\mathrm{O}$ from xylan), $1738 \mathrm{~cm}^{-1}$ to $1747 \mathrm{~cm}^{-1}$ (unconjugated $\mathrm{C}=\mathrm{O}$ stretch in xylan from acetic acid ester and pectin) $[16,17]$. Our results are consistent with the notion that crosslinked xylan or ferulate-polysaccharide-lignin complexes are in part responsible for the recalcitrance of cellulose microfibrils $[18,19]$. Similar results have been reported previously $[9,12]$ for barley straw where esterified pectin or xylan crosslinked to lignin was identified as the major factor responsible for the recalcitrance of these forages to mixed rumen enzymes as well as to commercial enzymes preparations. 


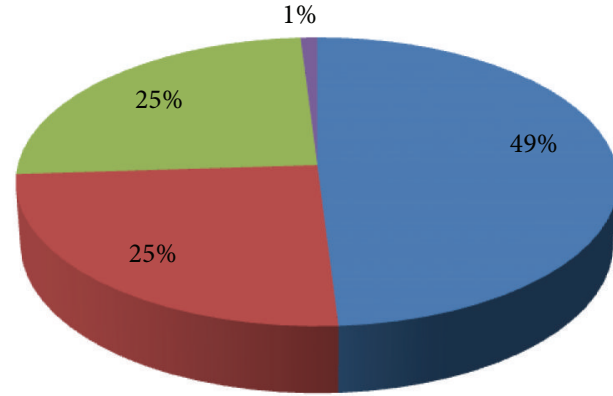
Accellerase 1500
Accellerase XC
EGL7A_THITE
E-BGLUC

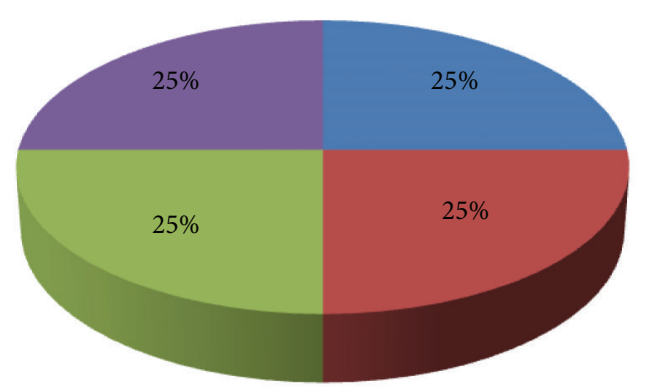

Accellerase 1500

Accellerase XC

AXE16B_ASPNG

E-BGLUC
Glucose prediction: $252.8 \mathrm{mg} / \mathrm{g}$

SE mean: 28.64

SE pred: 41.07

Xylose prediction: $78.52 \mathrm{mg} / \mathrm{g}$

SE mean: 2.69

SE pred: 3.87

Glucose prediction: $117.136 \mathrm{mg} / \mathrm{g}$

SE mean: 4.22

SE pred: 6.09

Xylose prediction: $63.69 \mathrm{mg} / \mathrm{g}$

SE mean: 2.80

SE pred: 4.04

(b)

FIGURE 1: Enzyme fingerprinting of barley silage (a) and tract indigested fiber residues (TIFR) (b) for glucose and xylose released.

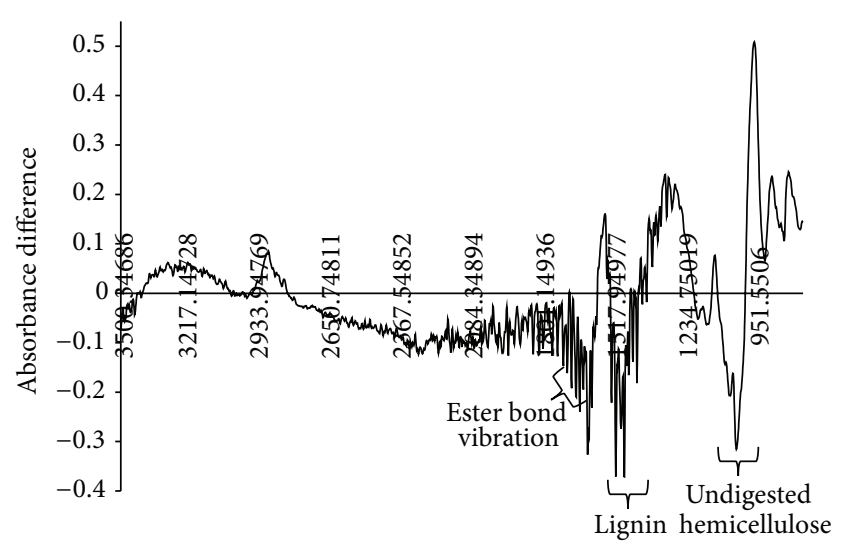

FIGURE 2: FTIR spectral difference for feed versus tract indigested fiber residues (TIFR) showing major undigested plant cell wall components after rumen digestion.
We hypothesize that prehydrolysis of the forage with efficient auxiliary enzymes like esterases prior to consumption may increase fiber digestibility in ruminants by reducing recalcitrant cross-linked xylan content. This would be beneficial to ruminant production in the form of increased efficiency of meat and milk production.

Based on the results from the enzyme fingerprinting (experiment 1) we selected recombinant enzymes (namely acetyl xylan esterase AXE16A_ASPNG and AXE16B_ASPNG, polygalacturonase PGA28A_ASPNG, arabinofuranosidase ABF54B_ASPNG, and ferulic acid esterase FAE 1a) and endoglucanase EGL7A_THITE for prehydrolysis with an aim to increase the sugar yield from substrates exposed to mixed rumen enzymes. We specifically selected barley straw as the substrate in experiment 2 with the expectation that it would represent even a more recalcitrant forage source than barley silage. The model predicted a significant increase in glucose 


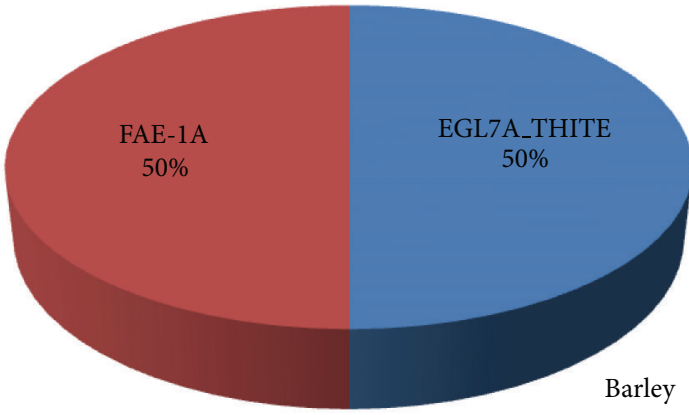

Prediction: 209.9

SE mean: 28.64

SE pred: 41.07

(a)

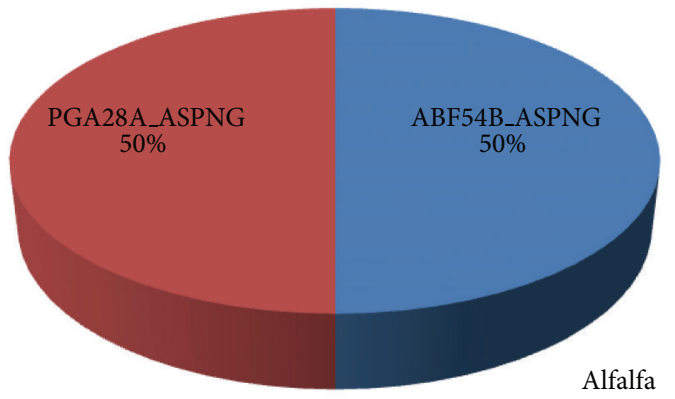

Prediction: 175.28

SE mean: 1.84

SE pred: 2.67

(b)

FIGURE 3: Optimization of enzyme ratios for enzyme prehydrolysis to aid high relative glucose yield from mixed rumen enzymes digestion of barley straw (a) and alfalfa hay (b).

yield as result of enzymatic prehydrolysis of alfalfa hay and barley straw prior to digestion by mixed rumen enzymes (Figure 3). Prehydrolysis of barley straw with a mixture of endoglucanase GH 7 (EGL7A_THITE) and feruloyl esterase (FAE 1a: 1:1) prior to exposure to mixed rumen enzymes resulted in a $100 \%$ increase in glucose release as compared to the untreated control (Figure 3(a)), while for alfalfa hay, a $75 \%$ higher glucose yield was predicted by the model as a result of enzymatic prehydrolysis of alfalfa with a 1:1 ratio of polygalacturonase (PGA28A_ASPNG) and arabinofuranosidase (ABF54B_ASPNG) prior to digestion by mixed rumen enzymes (Figure 3(b)). These results are in agreement with major structural disparity between alfalfa and barley plant cell walls. The carbohydrates within barley plant cell walls are mainly cellulose and hemicellulose with a negligible amount of pectin [20], whereas alfalfa cell wall contains pectin and xylan in roughly similar proportions, each accounting for $15-20 \%$ of total cell wall carbohydrates [21]. Effectiveness of esterase (FAE 1a) as a prehydrolysis for barley straw digestion by mixed rumen enzymes is in accordance with earlier reports regarding esterified cross-linkages being the major factor limiting the hydrolysis of barley straw by rumen microbes [9]. However, the hydrolysis of hemicellulose in alfalfa by mixed rumen enzymes was enhanced by the addition of polygalacturonase (PGA28A_ASPNG) and arabinofuranosidase (ABF54B_ASPNG). These results suggested that multienzyme mixtures have potential as feed additives by initiating degradation of plant structural polysaccharides prior to ingestion by the ruminant animal.
Predictions made by our micromodel were also validated in scale-up assays that used a solid load of $2 \%$ $\mathrm{w} / \mathrm{v}$ of barley straw or alfalfa hay. The effect of enzyme prehydrolysis on the subsequent enhancement of cell wall hydrolysis was studied by sequential or simultaneous addition of recombinant enzymes to mixed rumen enzymes for barley straw and alfalfa hay. Results of hydrolysis of barley straw and alfalfa hay by mixed rumen enzymes after $48 \mathrm{~h}$ of prehydrolysis by endoglucanase EGL7A_THITE (50\%) and ferulic acid esterase FAE 1a (50\%) for barley straw and polygalacturonase PGA28A_ASPNG (50\%) and arabinofuranosidase ABF54B_ASPNG (50\%) for alfalfa hay confirmed that these mixtures increased the release of glucose and xylose $(P<0.05)$ as a result of prehydrolysis (Figures 4(a) and 4(b)). Supplementation of rumen mixed enzymes with endoglucanase EGL7A_THITE (50\%) and ferulic acid esterase FAE 1a (50\%) during the digestion of barley straw and polygalacturonase PGA28A_ASPNG (50\%) and arabinofuranosidase ABF54B_ASPNG (50\%) with alfalfa hay enhanced $(P<0.05)$ digestion as compared to mixed rumen enzymes alone (Figures 4(c) and 4(d)). A direct relationship was observed between xylan conversion (fraction of available xylan converted) and glucose conversion (fraction of available glucan conversion) during the hydrolysis of plant cell walls (Figure 5). However, a stronger correlation between xylan and glucan digestion with added auxiliary enzymes for optimized mixed rumen enzymes (Figure 5) suggested improved glucan conversion, perhaps due to better xylan saccharification. 


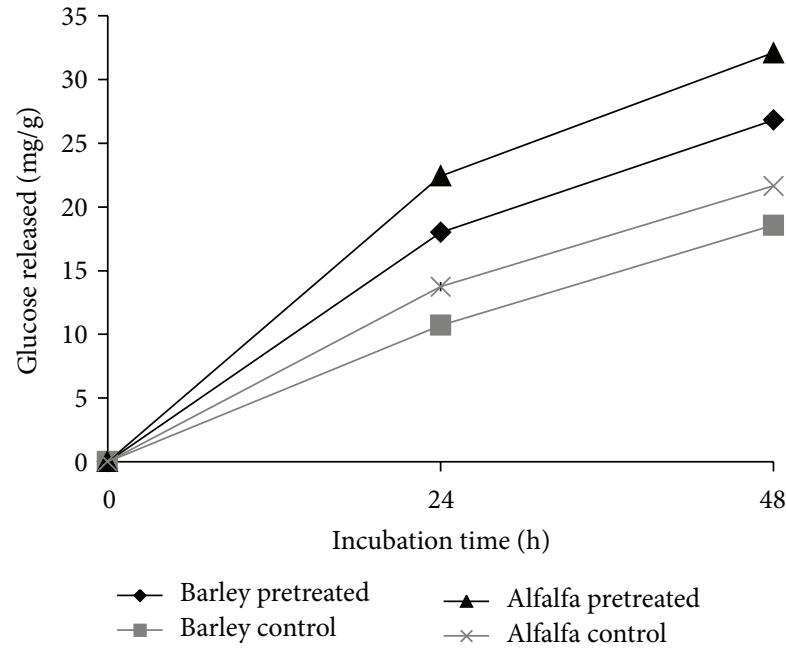

(a)

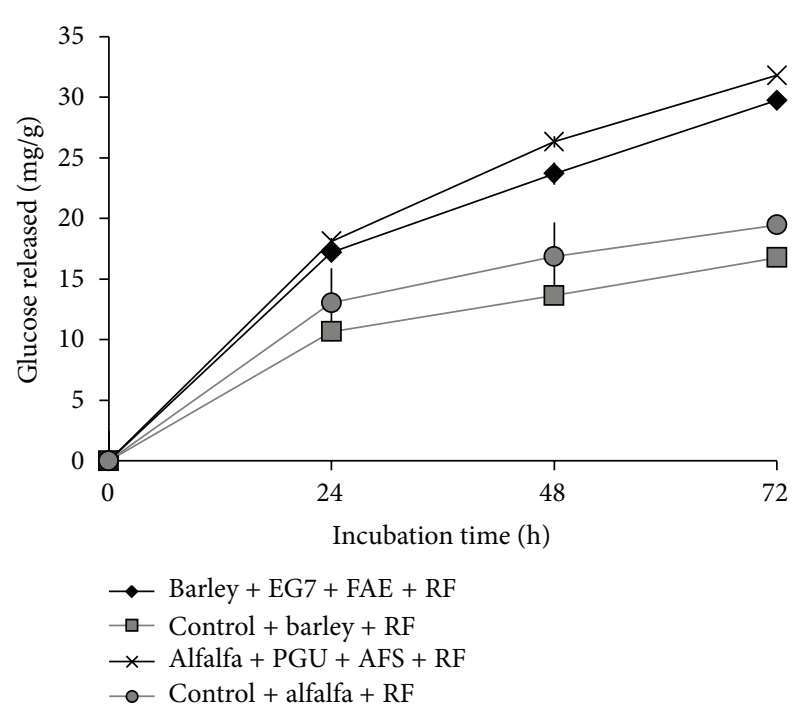

(c)

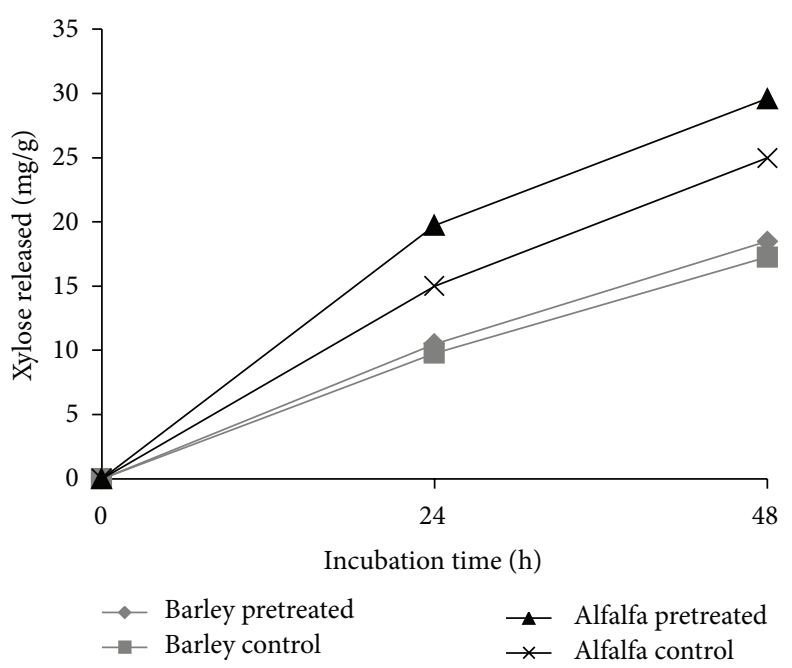

(b)

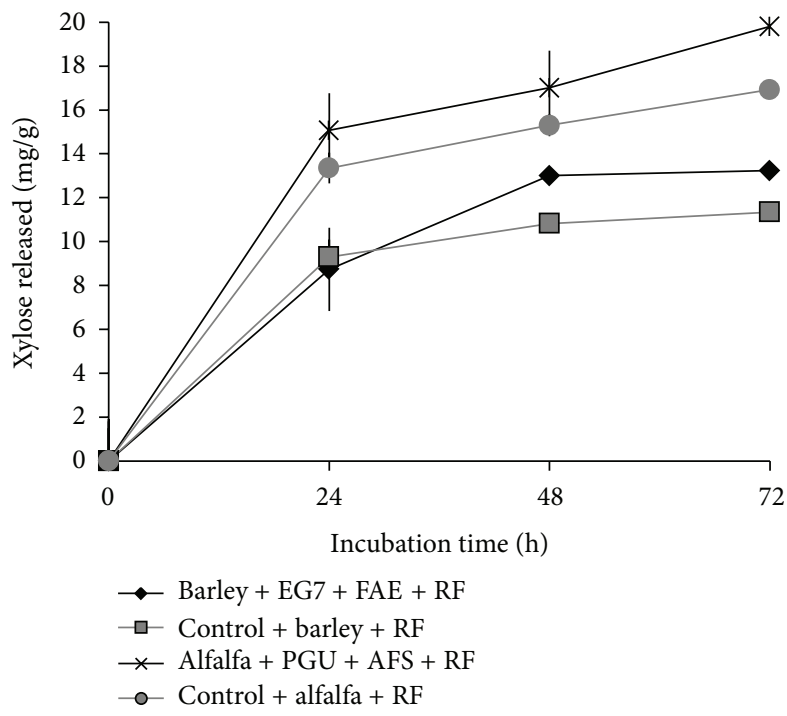

(d)

Figure 4: Glucose and xylose released as result of sequential ((a), (b)) and simultaneous ((c), (d)) hydrolysis of barley straw and alfalfa (biomass load: $2 \%, 30 \mathrm{mg}$ of protein load/g of glucan in $5 \mathrm{~mL}$ reaction volume). Error bars (often invisible) represent $\mathrm{SD}$ of the mean $(n=8)$.

Comprehensive digestion of cell wall requires a battery of carbohydrases. Moreover, yields of recombinant enzymes from expression systems are often low. Hence, a microassay for screening novel enzymes against diverse biomass with ability to study synergy among hydrolases at low protein load is critical for development of enzyme formulations as additives to enhance ruminal digestion. In this study we successfully developed a microassay in combination with experimental design, to screen a number of recombinant enzymes at low protein loads, to enhance ruminal digestion of barley straw and alfalfa through augmentation of natural enzymatic activity in the rumen. Development of enzyme formulations that further enhance the utilization of low quality cellulosic feedstocks will ensure the sustainability of the beef industry in an environment of increasing demand for human food.

\section{Conclusion}

Enzyme fingerprinting was successfully used to identify principal recalcitrant constituent of barley silage. Crosslinked hemicelluloses as well as layered structure of cellulose and xylan were identified as prime recalcitrant factors to digestion. Partial digestion of hemicellulose in alfalfa hay and barley straw prior to ingestion with a cocktail of auxiliary enzymes significantly improved the hydrolysis of cellulose by mixed rumen enzymes. These results strengthen the rational of enzyme pretreatments targeting particular forage types. 


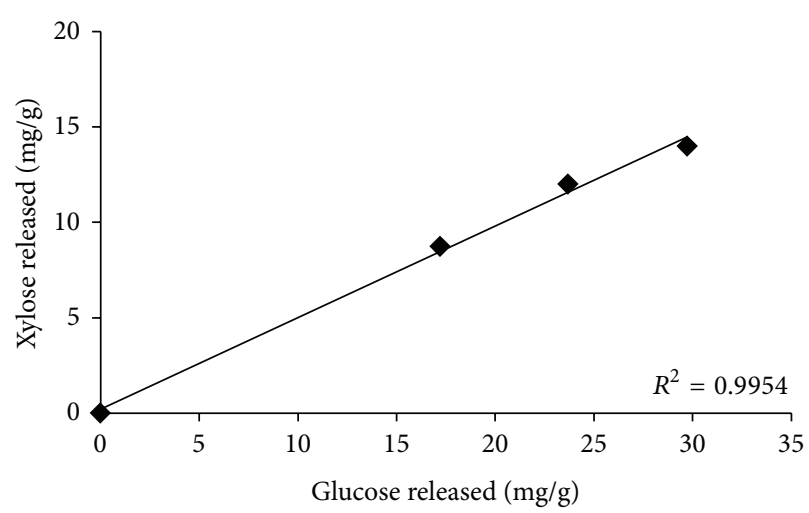

(a)

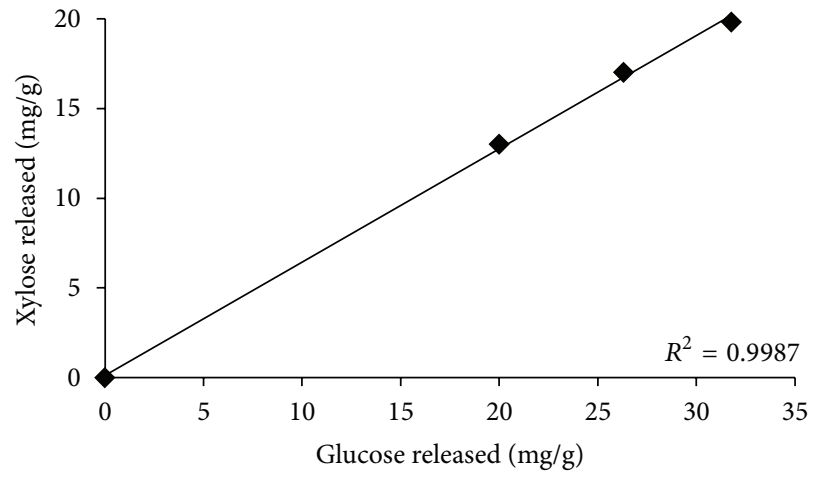

(c)

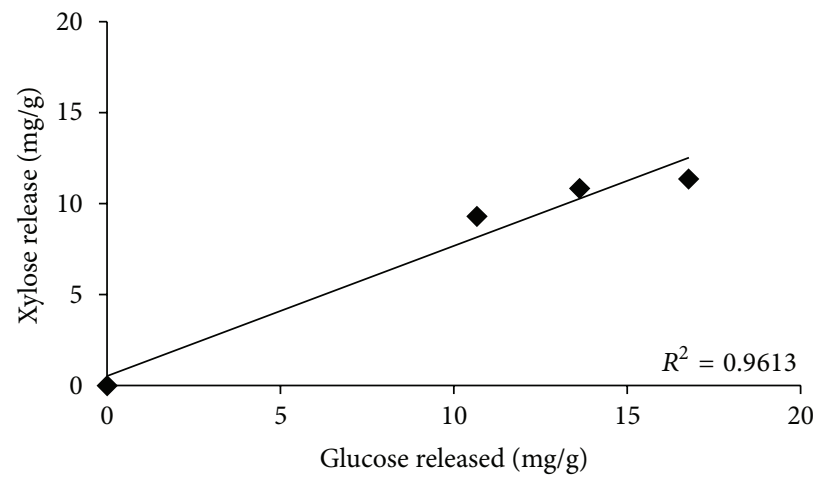

(b)

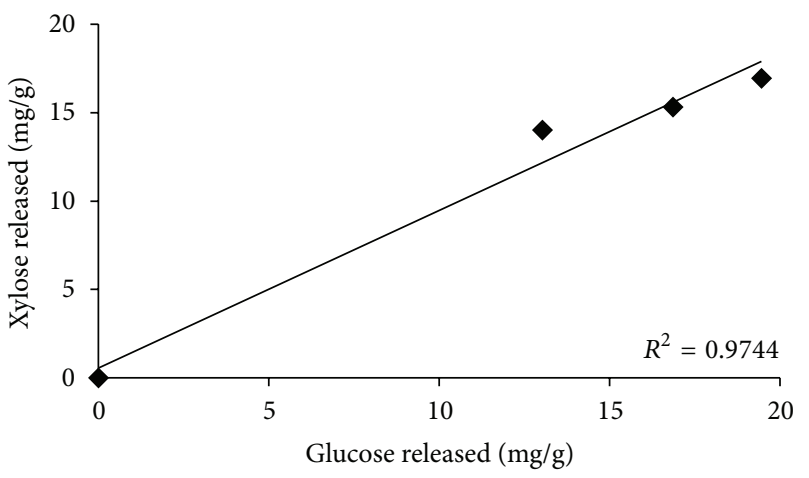

(d)

FIGURE 5: Change in glucan conversion plotted against change in xylan conversion for simultaneous hydrolysis of barley straw (a) alfalfa hay (c) by optimized enzyme mix and their respective controls ((b), (d); only rumen mix enzymes). Optimized enzyme mix composition used for barley straw and alfalfa hay digestion was identical to those used in Figure 3. Final enzymes load of $30 \mathrm{mg} / \mathrm{g}$ glucan with $2 \%$ solid load in $5 \mathrm{~mL}$ reaction volume was used.

These same approaches could be used to improve the value of animal waste as a feedstock for biofuel production.

\section{Conflict of Interests}

The authors declare that there is no conflict of interests regarding the publication of this paper.

\section{Acknowledgments}

Authors are grateful to Genencor (Danisco US Inc., Genencor Division, Rochester, NY) for generously donating samples of Accellerase 1500 and Accellerase XC. This work was supported by the Cellulosic Biofuel Network of Agriculture and Agri-Food Canada, Genome Canada, Genome Alberta, and Genome Quebec.

\section{References}

[1] R. D. Hatfield and J. Ralph, "Modelling the feasibility of intramolecular dehydrodiferulate formation in grass walls," Journal of the Science of Food and Agriculture, vol. 79, no. 3, pp. 425-427, 1999.
[2] G. A. Varga and E. S. Kolver, "Microbial and animal limitations to fiber digestion and utilization," The Journal of Nutrition, vol, 127, no. 5, pp. 819S-823S, 1997.

[3] H. L. Classen, H. Graham, J. Inborr, and M. R. Bedford, "Growing interest in feed enzymes to lead to new products," Feedstuffs, vol. 63, pp. 22-24, 1991.

[4] M. R. Bedford, "Mode of action of feed enzymes," The Journal of Applied Poultry Research, vol. 2, pp. 85-92, 1993.

[5] V. L. Nsereko, K. A. Beauchemin, D. P. Morgavi et al., "Effect of a fibrolytic enzyme preparation from Trichoderma longibrachiatum on the rumen microbial population of dairy cows," Canadian Journal of Microbiology, vol. 48, no. 1, pp. 14-20, 2002.

[6] G. Banerjee, S. Car, J. S. Scott-Craig, M. S. Borrusch, and J. D. Walton, "Rapid optimization of enzyme mixtures for deconstruction of diverse pretreatment/biomass feedstock combinations," Biotechnology for Biofuels, vol. 3, article 22, 2010.

[7] D. Gao, S. P. S. Chundawat, C. Krishnan, V. Balan, and B. E. Dale, "Mixture optimization of six core glycosyl hydrolases for maximizing saccharification of ammonia fiber expansion (AFEX) pretreated corn stover," Bioresource Technology, vol. 101, no. 8, pp. 2770-2781, 2010.

[8] H. Billard, A. Faraj, N. Lopes Ferreira, S. Menir, and S. HeissBlanquet, "Optimization of a synthetic mixture composed of 
major Trichoderma reesei enzymes for the hydrolysis of steamexploded wheat straw," Biotechnology for Biofuels, vol. 5, article 9, 2012.

[9] A. Badhan, Y. Wang, R. Gruninger et al., "Formulation of enzyme blends to maximize the hydrolysis of alkaline peroxide pretreated alfalfa hay and barley straw by rumen enzymes and commercial cellulases," BMC Biotechnology, vol. 14, article 31, 2014.

[10] S. P. S. Chundawat, V. Balan, and B. E. Dale, "High-throughput microplate technique for enzymatic hydrolysis of lignocellulosic biomass," Biotechnology and Bioengineering, vol. 99, no. 6, pp. 1281-1294, 2008.

[11] D. Vyas, E. J. McGeough, S. M. McGinn, T. A. McAllister, and K. A. Beauchemin, "Effect of Propionibacterium spp. on ruminal fermentation, nutrient digestibility, and methane emissions in beef heifers fed a high-forage diet," Journal of Animal Science, vol. 92, no. 5, pp. 2192-2201, 2014.

[12] A. Badhan, L. Jin, Y. Wang et al., "Expression of a fungal ferulic acid esterase in alfalfa modifies cell wall digestibility," Biotechnology for Biofuels, vol. 7, no. 1, article 39, 2014.

[13] R. B. Hespell and M. A. Cotta, "Degradation and utilization by Butyrivibrio fibrisolvens H17c of xylans with different chemical and physical properties," Applied and Environmental Microbiology, vol. 61, no. 8, pp. 3042-3050, 1995.

[14] N. Carpita and M. McCann, "The cell wall," in Biochemistry and Molecular Biology of Plants, B. Buchanan, W. Gruissmen, and R. Jones, Eds., pp. 52-108, John Wiley \& Sons, Somerset, NJ, USA, 2000.

[15] Y. Sun and J. Cheng, "Hydrolysis of lignocellulosic materials for ethanol production: a review," Bioresource Technology, vol. 83, no. 1, pp. 1-11, 2002.

[16] M. Kacuráková, P. Capek, V. Sasinková, N. Wellner, and A. Ebringerová, "FT-IR study of plant cell wall model compounds: pectic polysaccharides and hemicelluloses," Carbohydrate Polymers, vol. 43, no. 2, pp. 195-203, 2000.

[17] G. Zhou, G. Taylor, and A. Polle, "FTIR-ATR-based prediction and modelling of lignin and energy contents reveals independent intra-specific variation of these traits in bioenergy poplars," Plant Methods, vol. 7, no. 1, article 9, 2011.

[18] Y. Wang, B. M. Spratling, D. R. Zobell, R. D. Wiedmeier, and T. A. McAllister, "Effect of alkali pretreatment of wheat straw on the efficacy of exogenous fibrolytic enzymes," Journal of Animal Science, vol. 82, no. 1, pp. 198-208, 2004.

[19] M. J. Selig, E. P. Knoshaug, W. S. Adney, M. E. Himmel, and S. R. Decker, "Synergistic enhancement of cellobiohydrolase performance on pretreated corn stover by addition of xylanase and esterase activities," Bioresource Technology, vol. 99, no. 11, pp. 4997-5005, 2008.

[20] K. Pahkala, M. Kontturi, A. Kallioinen et al., "Production of bioethanol from barley straw and reed canary grass: a raw material study," in Proceedings of the 15th European Biomass Conference and Exhibition, pp. 154-157, Berlin, Germany, 2007.

[21] B. S. Dien, H.-J. G. Jung, K. P. Vogel et al., "Chemical composition and response to dilute-acid pretreatment and enzymatic saccharification of alfalfa, reed canarygrass, and switchgrass," Biomass and Bioenergy, vol. 30, no. 10, pp. 880-891, 2006. 

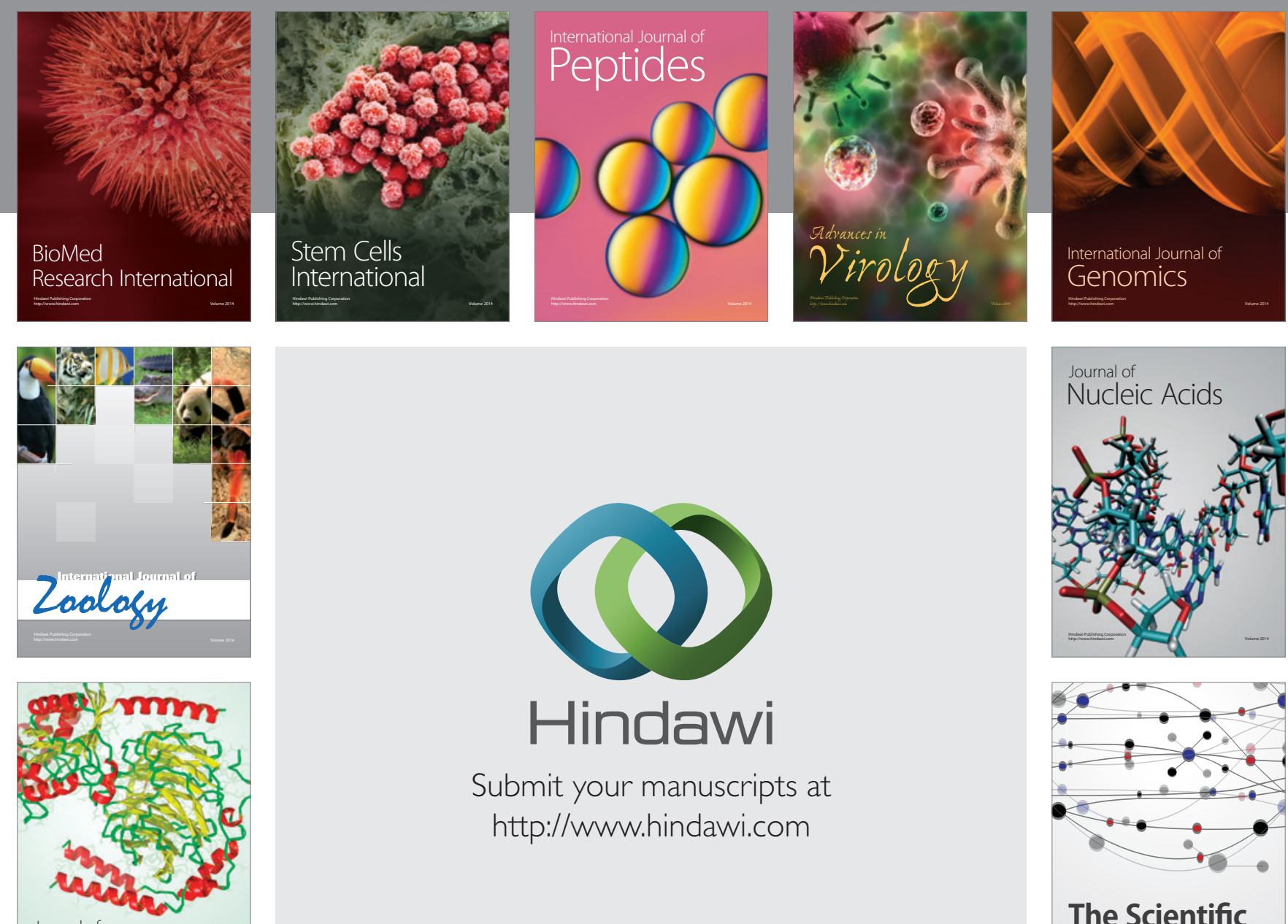

Submit your manuscripts at

http://www.hindawi.com

Journal of
Signal Transduction
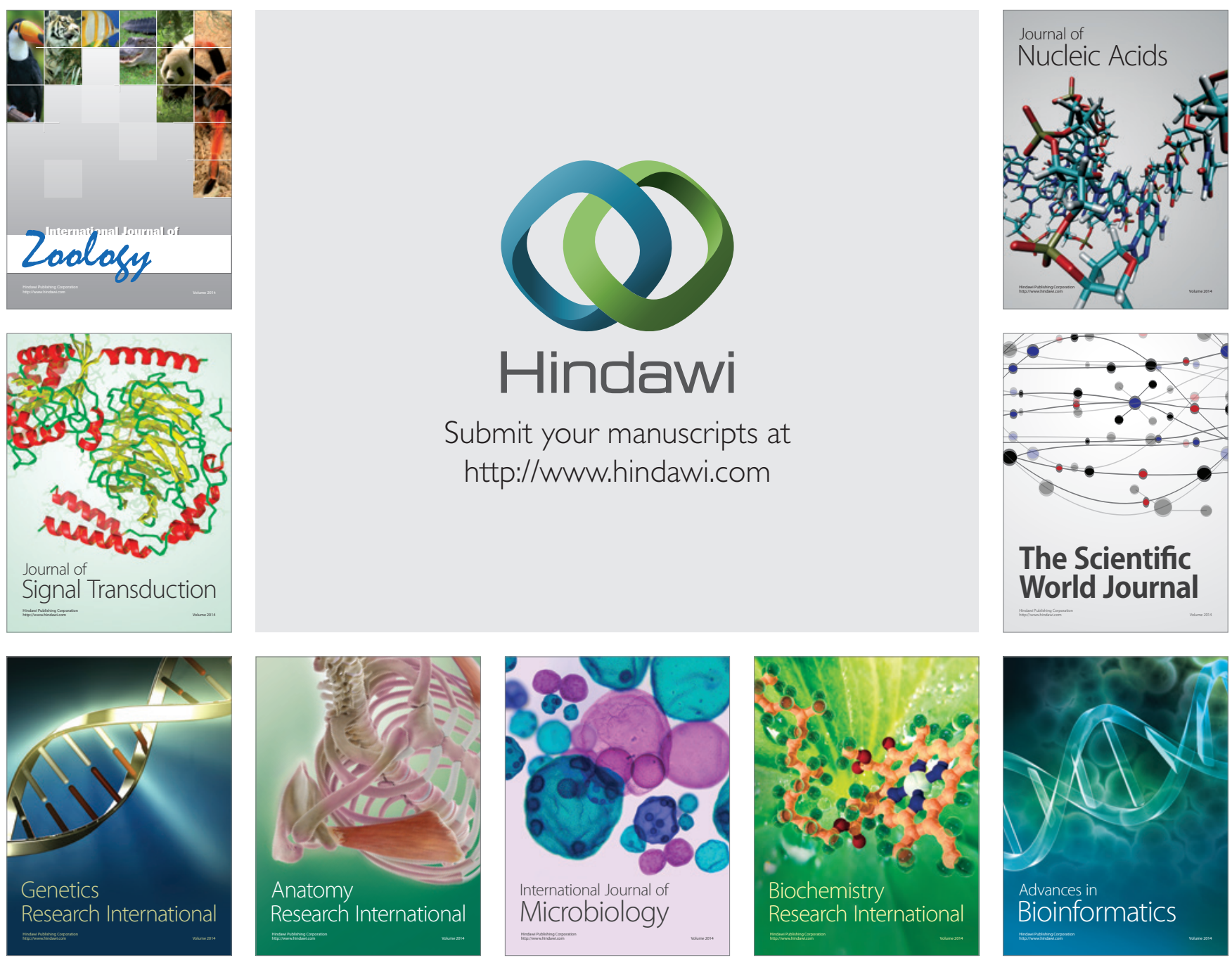

The Scientific World Journal
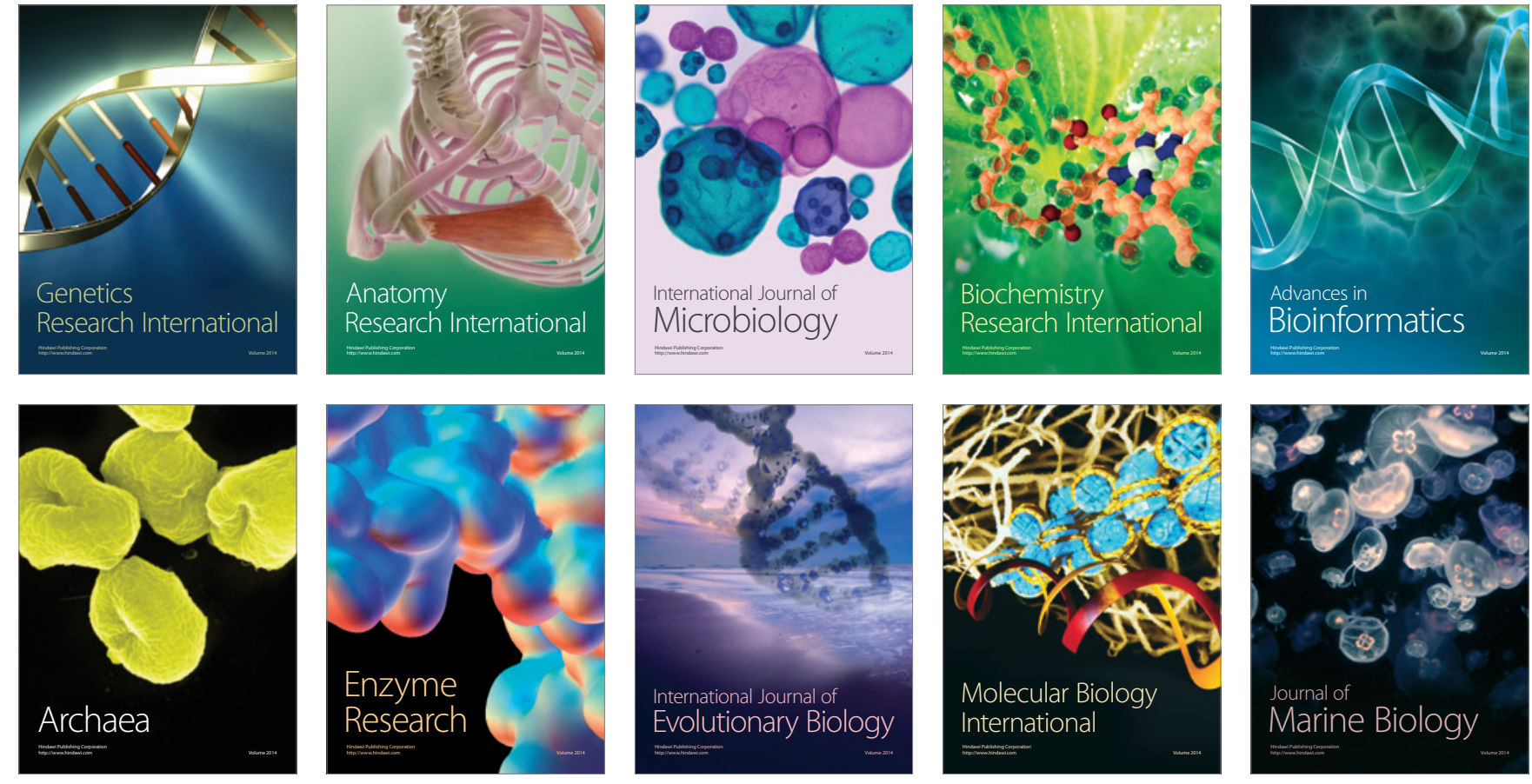